\title{
Nitrogen Loads in Groundwater Entering Back Bays and Ocean from Fire Island National Seashore, Long Island, New York
}

Photograph of ocean shore between Watch Hill and Davis Park showing peat deposits occasionally uncovered on the Atlantic Ocean beaches of Fire Island, Suffolk County, N.Y. Groundwater discharge shown in the foreground can transport freshwater and contaminants from the island to the adjacent back bays and ocean. (Photograph from Paula Valentine, National Park Service)

- About 2.2 million people visit Fire Island each year. The arrival of summer residents and vacationers increases the population 50-fold.

- Wastewater from most septic systems discharges directly into the shallow (water-table) aquifer. The associated nutrients, pathogens, and organic compounds can eventually seep into back-barrier estuaries and threaten their ecological health.

- Elevated concentrations of nutrients in groundwater that discharges to surface waters can lead to increased production of phytoplankton and macroalgae; these, in turn, can cause oxygen depletion, declines in estuarine fish and shellfish communities, and loss of submerged seagrass habitat.
- Simulations of groundwater discharge from the shallow aquifer indicate that nearly 80 percent of the total discharge enters the back-barrier estuaries; the rest discharges to the ocean or below the seabed as subsea outflow.

- The travel time of groundwater through the shallow aquifer to discharge zones varies with distance from the recharge area. Particle-tracking analysis indicates that the mean travel time is 3.4 years, and virtually all groundwater is younger than 20 years.

- Further water-level and water-quality monitoring at selected locations would allow development of management strategies to protect back-barrier ecosystems from the effects of wastewater discharging from the aquifer. 


\section{INTRODUCTION}

Fire Island is a barrier island that lies south of central Long Island, N.Y. It is about $60 \mathrm{~km}$ (37 mi) long and $0.5 \mathrm{~km}$ (1/4 mi) wide and is bounded by the Great South Bay, Narrow Bay, and Moriches Bay estuaries to the north; by the Atlantic Ocean to the south; by Fire Island Inlet to the west; and by Moriches Inlet to the east (fig. 1). Fire Island National Seashore (FIIS) encompasses a 42-km (26-mi) length of Fire Island that is bordered by Robert Moses State Park to the west and Smith Point County Park to the east (fig. 2). Interspersed throughout FIIS are 17 residential beach communities that together contain about 4,100 homes.

The barrier island's summer population increases 50-fold through the arrival of summer residents and vacationers. The National Park Service (NPS) has established several facilities on the island to accommodate visitors to FIIS. About 2.2 million people visit at least one of the 17 communities and (or) Smith Point County Park, the waterways surrounding Fire Island, or a FIIS facility annually (National Park Service, 2007). Combined visitation on a peak-season weekend day can be as high as 100,000 (National Park Service, 2002).

Most homes and businesses in the 17 barrier-island communities discharge untreated wastewater directly to the shallow (water-table) aquifer through private septic systems and cesspools; the NPS facilities discharge wastewater to this aquifer through leach fields and cesspools. (The community of Ocean Beach (fig. 2) has a treatment plant that discharges to tidewater.) Contaminants in sewage entering the shallow groundwater move through the flow system and are ultimately discharged to adjacent marine surface waters, where they can pose a threat to coastal habitats. A contaminant of major concern is nitrogen, which is derived from fertilizers and human waste. The continuous inflow of nitrogen to surfacewater bodies can lead to increased production of phytoplankton and macroalgae, which in turn can cause oxygen depletion, decreases in size of estuarine fish and shellfish communities, and loss of submerged seagrass habitat through light limitation (Valiela and others, 1992).

The FIIS boundary extends roughly $1.2 \mathrm{~km}(0.8 \mathrm{mi})$ into the back-barrier estuaries of Great South Bay, Narrow Bay, and Moriches Bay (fig. 1). Within this estuarine zone are extensive areas of seagrass, shellfish, and finfish habitat, as well as intense recreational activity (Bokuniewicz and others, 1993). Management strategies for protection of these habitats require data on (1) concentrations and movement of nutrients and other human-derived contaminants that enter the groundwater system from on-site septic systems, and (2) aquifer characteristics and groundwater flow patterns. These data can then be used in three-dimensional flow models of the shallow aquifer system to predict the rates of groundwater discharge to the marine surface waters that bound Fire Island and the concentrations of nitrogen entering these water bodies from the aquifer's discharge zones.

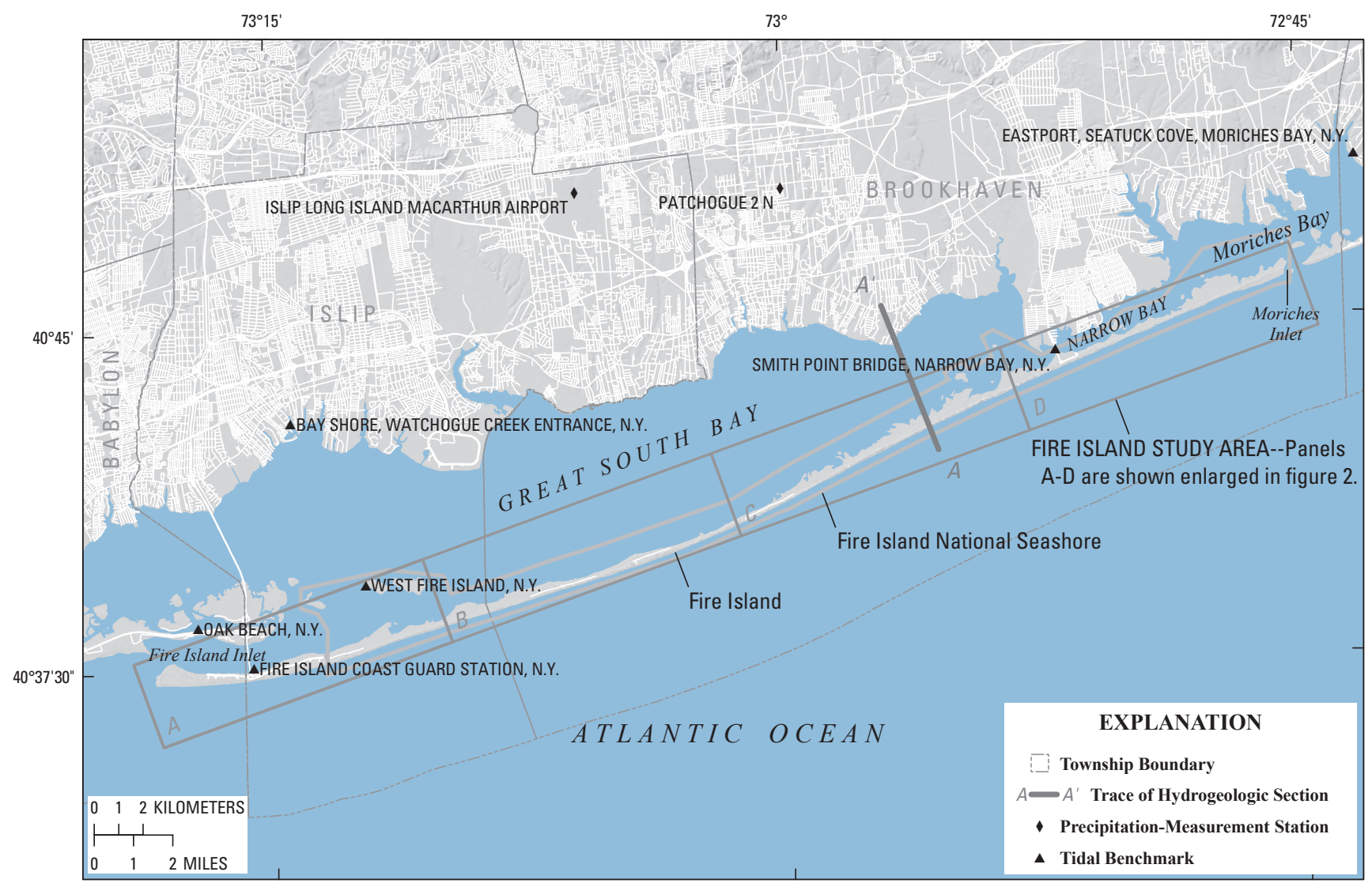

Base from The National Map,

Universal Transverse Mercator projection, NAD 83, Zone 18

Figure 1. Map shows the location of the Fire Island National Seashore study area in Suffolk County, N.Y. 

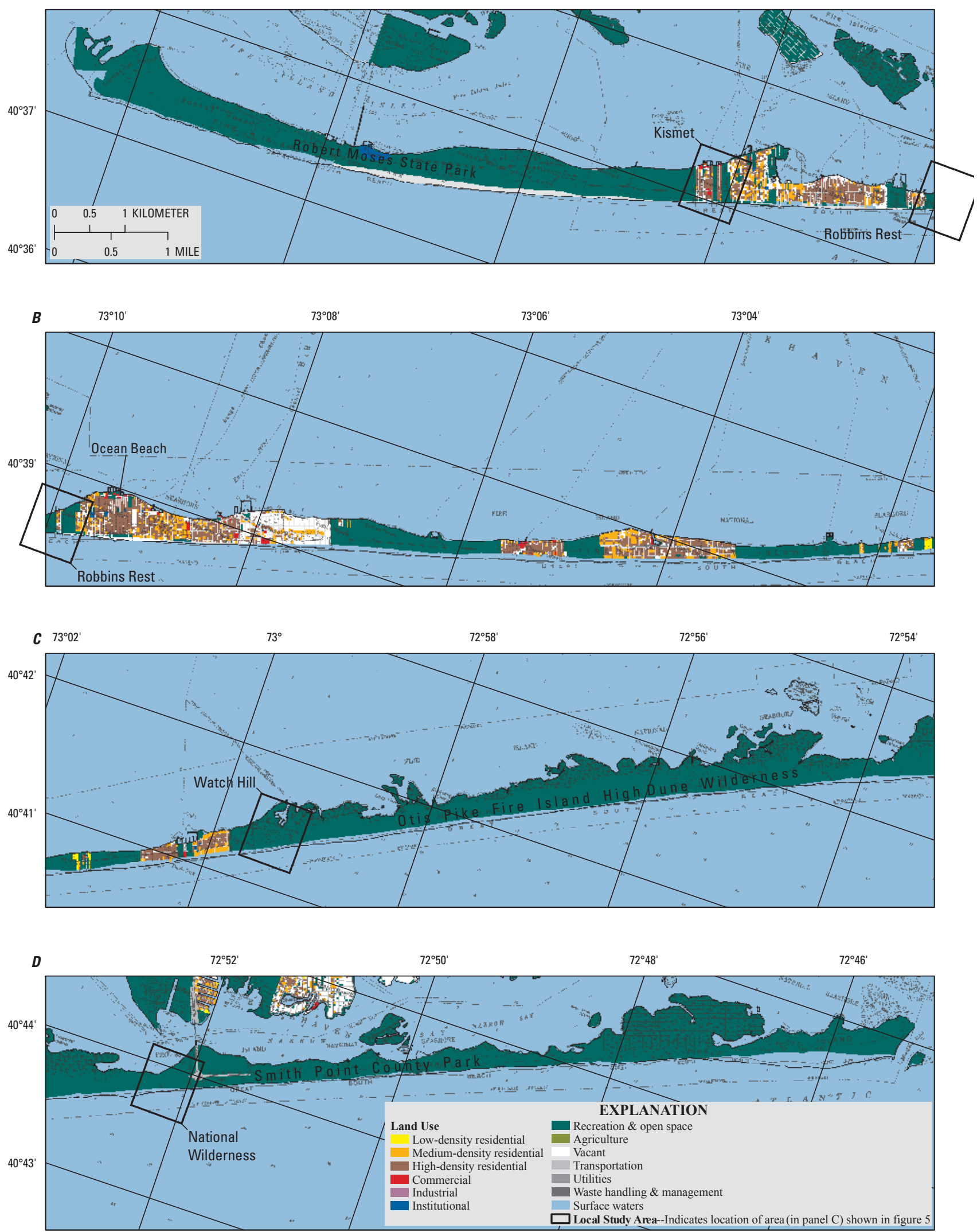

Base from New York State Department of Transportation planimetric quadrangles, 1991, 1:24,000, Universal Transverse Mercator projection, NAD 83, Zone 18

Figure 2. Maps show the type of land use and locations of the four local study areas-Kismet, Robbins Rest, Watch Hill, and National Wilderness - on Fire Island, Suffolk County, N.Y. (Locations of the areas shown in panels $A, B, C$, and $D$ are shown in figure 1.) 
In 2004, the U.S. Geological Survey (USGS), in cooperation with the NPS, began a 3-year investigation to (1) measure groundwater levels within four local study areas at FIIS, (2) collect groundwater samples from these areas for nutrient (nitrogen) analysis, (3) develop a three-dimensional model of the hydrologic system and adjacent saltwater bodies for groundwater-flow delineation and particle tracking, and (4) apply the results of groundwater-discharge simulations to calculate the annual nitrogen loads in these discharges, particularly those entering Great South Bay, which together with the other back bays receives an estimated 80 percent of the total groundwater discharge from Fire Island.

- The four areas on which the investigation focused were the communities of Kismet and Robbins Rest, the NPS Visitor Center at Watch Hill, and the undeveloped Otis Pike Fire Island High Dune Wilderness (shown in panels A, B, C, and D in fig. 2); these were selected to represent the major land uses and corresponding nitrogen concentrations at FIIS.

- Thirty-five observation wells were installed within FIIS to document the stratigraphy, establish a water-table-monitoring network, and collect water-quality data.

- A three-dimensional flow model was constructed to simulate groundwater discharge and to calculate the annual nitrogen loads in these discharges, particularly those entering backbarrier estuaries, from freshwater discharge zones.

- The network of observation wells provides a foundation for long-term monitoring of groundwater levels and chemical quality throughout the National Seashore, and the model can be used in subsequent studies to simulate the transport of nitrogen and other contaminants through the aquifer system.
This paper describes the hydrogeologic system that underlies FIIS and presents results of the model simulations. It also (1) depicts the patterns of groundwater flow within the freshwater aquifer and adjacent saline subsurface, (2) presents the yearly amounts of freshwater discharged to the back bays and the ocean from the shallow aquifer, (3) presents a discussion on the quality of water in the freshwater aquifer and presents the annual nitrogen loads discharging to coastal waters, (4) provides the estimated travel time of water from recharge areas to these discharge zones, and (5) presents a discussion of model limitations and considerations for future groundwater monitoring. All information presented herein is given in greater detail in Schubert (2010).

\section{Land Use}

About 3 percent of the land area on Fire Island is vacant (Carl Lind, Suffolk County Department of Planning, written commun., 2006). About 81 percent is recreational and open space (fig. 3A), including a part of the island that extends from just west of Smith Point County Park to just east of the NPS Visitor Center at Watch Hill (fig. 2) that Congress designated as a National Wilderness Area in 1980. About 12 percent of the land area is residential (fig. 3B), although most residences are occupied only during summer months (National Park Service, 2003). About 8 percent of the land area is classified as high-density residential with at least five dwelling units per acre; 4 percent is medium density (between one and five dwelling units per acre); and less than 1 percent is low density (one dwelling unit per acre or less). The 3 percent of the remaining land area is categorized as commercial, industrial, institutional, transportation, utilities, or waste handling and waste management.

\section{A Fire Island land use - Percent of total area $\quad \boldsymbol{B}$ Fire Island residential density-}

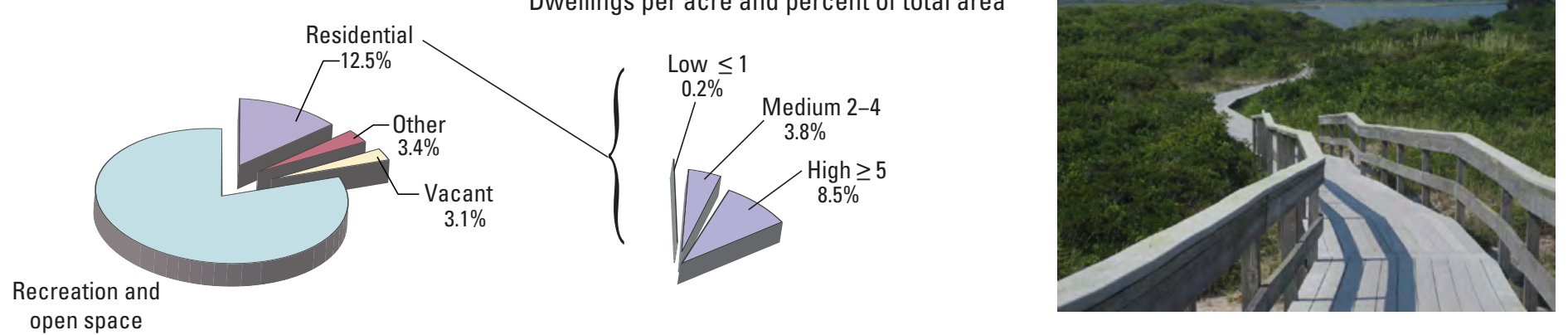

open space

$81 \%$

Figure 3. Pie charts show $(A)$ the percent of land used for recreation and open space, residential and other development, and vacant areas and $(B)$ residential density, in number of dwellings per acre and the percent of total land use, in the Fire Island study area, Suffolk, County, N.Y. Photographs: (top) vegetation in Otis Pike Fire Island High Dune Wilderness (courtesy of Stevan/wikipedia. org); (bottom) residential density in the Kismet area of Fire Island. (Photograph courtesy of the National Park Service.)

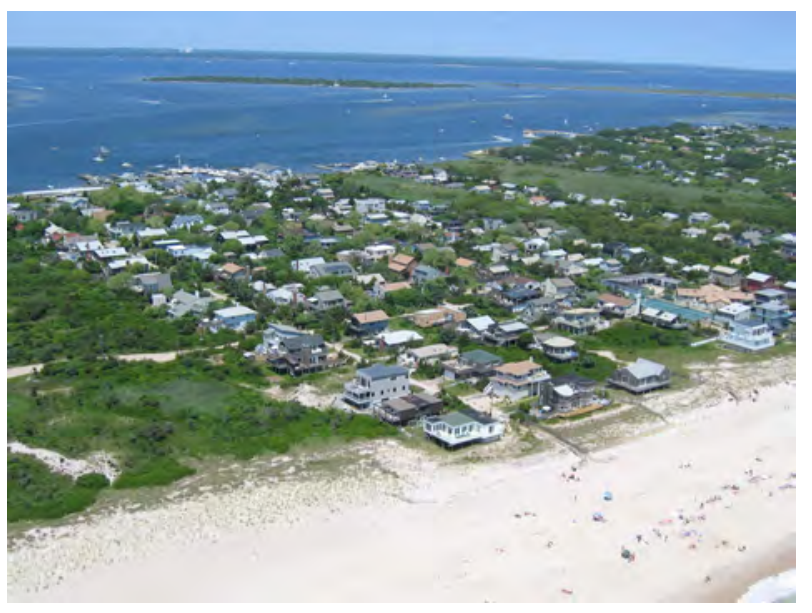




\section{Water Supply}

Fire Island is served by 10 public water-supply systems. All public water supply for the barrier-island communities and for all NPS, State, and County park facilities is pumped from the underlying aquifer system; a small fraction of this pumpage occurs on the Long Island mainland. Virtually all water is withdrawn from the confined Magothy aquifer because the overlying upper glacial aquifer, which historically was used to supply summer residences, now contains elevated concentrations of chloride, nitrate, and coliform bacteria from septic waste-disposal systems and has largely been abandoned (Leggette, Brashears \& Graham, Inc., 1996). The Magothy aquifer is protected from contamination in the surficial freshwater lens by saline water and a confining unit (Gardiners Clay) .

Most public-supply water on Fire Island is ultimately returned to the shallow aquifer, primarily through onsite wastewater disposal systems and, to a lesser extent, as leakage from the water-distribution system; the remainder is lost as consumptive use (such as for irrigation). In unsewered areas of Long Island, about 85 percent of total public-supply pumpage is returned to the water table-about 70 percent through wastewater-disposal systems and 15 percent through leaky water mains and sewers (Franke and McClymonds, 1972). In sewered areas, wastewater generally is routed to a sewagetreatment plant, from which the effluent discharges to coastal water bodies.

\section{HYDROGEOLOGIC SETTING}

The hydrogeologic system was characterized from the results of exploratory drilling, geophysical surveys, water-level monitoring, and water sampling and analysis.

\section{Aquifer System}

Fire Island is underlain by a complex aquifer system consisting of unconsolidated glacial, lacustrine, deltaic, and marine deposits of clay, silt, sand, and gravel that range in age from Late Cretaceous to Holocene (fig. 4). These deposits overlie a southward sloping basement complex of crystalline bedrock of Precambrian and (or) Paleozoic age. Fresh groundwater in the shallow (water-table) aquifer is contained within a hydraulically isolated flow system within the Holocene and Pleistocene units and is not connected with the underlying confined (Late Cretaceous) Magothy aquifer from which the island's freshwater supply is obtained. The shallow aquifer extends laterally beneath adjacent marine water bodies and is bounded below by the Gardiners Clay confining unit. The watertable flow system is the unit of concern in this study because it receives the wastewater discharged from septic systems, which contains a variety of contaminants. The underlying Cretaceous units were not considered in this investigation. A generalized vertical section depicting the geometry of major hydrogeologic units underlying Fire Island is presented in figure 4.

\section{Groundwater Levels, Quality, and Discharge}

Water levels were measured on October 31 and November 1, 2005, to depict the distribution of hydraulic head on Fire Island for flow-model calibration (see figures 5 and 6 for examples from Watch Hill study area). The measurements were made within 1 hour of the predicted time of low tide to minimize local differences resulting from tidal fluctuations. In addition, one well in each of the four local study areas (shown in panels A-D in fig. 2) was instrumented with a continuous water-level recorder to document the groundwater fluctuations caused by tides, recharge from precipitation, and other factors such as wave height and wastewater disposal.

Water levels were generally found to increase with proximity to the ocean and were highest at wells nearest the ocean or just inland from it. Water levels at inland wells increased with increasing barrier-island width because the widest areas receive the greatest amount of recharge. These results indicate that the island's groundwater divide is skewed strongly toward the south (ocean) shore, probably in response to the combined effects of waves breaking (wave setup and setdown) and asymmetrical tidal infiltration and seepage (tidal pumping), both of which can elevate the water table along this shore to create a condition commonly referred to as water-table overheight (Nielsen, 1990; Hanslow and Nielsen, 1993; Turner and others, 1996; Nielsen, 1999).

Water samples were collected from the 35 observation wells to define the spatial distribution of total nitrogen (TN) concentrations from wastewater, fertilizer, and (or) other human-derived sources. A subset of these wells was resampled during March, August, and September of 2006 to assess the seasonal variability of TN concentrations. The highest TN concentrations (up to $10 \mathrm{mg} / \mathrm{L}$ ) were found downgradient from the Watch Hill leach field, which receives sewage from the park's visitor center; the lowest (less than $0.1 \mathrm{mg} / \mathrm{L}$ ) were within the National Wilderness (fig. 2). The primary form of nitrogen in groundwater in the Watch Hill vicinity was ammonia (fig. 5), whereas the primary form within the National Wilderness was nitrate. Both forms were common near Kismet and Robbins Rest.

Water in the freshwater flow system either discharges to shore and subsea-discharge areas or is lost through wetland evapotranspiration. Most freshwater discharge occurs as shoreline and subsea underflow, but the diffuse character and location of this outflow make the rate difficult to measure.

\section{MODEL SIMULATIONS}

A three-dimensional, variable-density flow model of the shallow-aquifer system and adjacent marine surface waters was developed to simulate the rates and directions of groundwater flow. Model development included the design of the model grid and the assignment of appropriate boundary conditions and aquifer properties. An example of vertical model discretization along column 569 (near location of section D-D' shown in fig. 5) is presented in figure 7.

The model was calibrated to water levels measured in 2005 and pumpage records provided by several local agencies. The variable-density groundwater flow model SEAWAT-2000 (Langevin and others, 2003) was used in the analysis. The simulation provided estimates of groundwater discharges from the shallow aquifer system to back-barrier estuaries and the ocean; these discharge values were then multiplied by representative nitrogen concentrations to obtain the annual nitrogen loads in these discharges. 


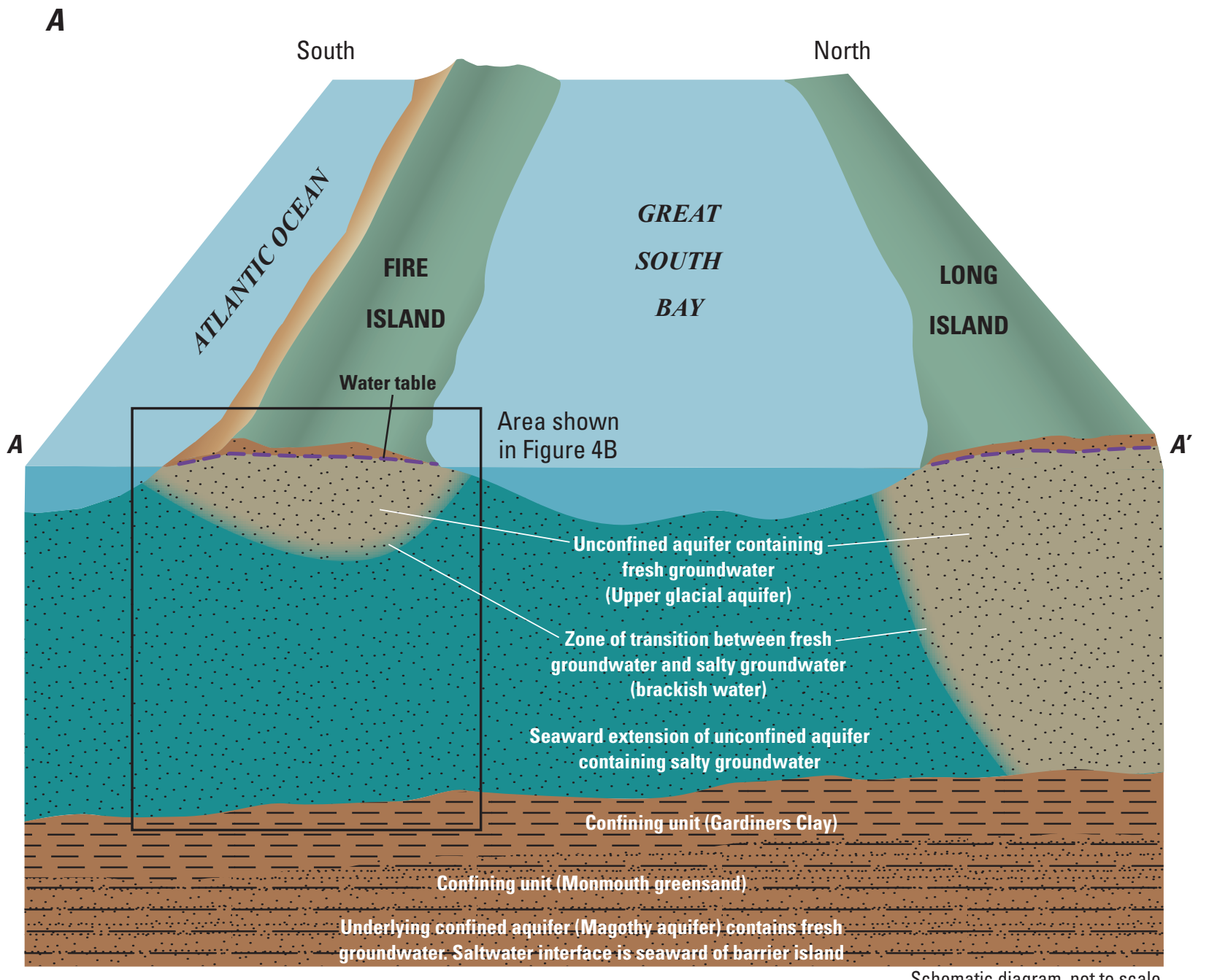

Schematic diagram, not to scale

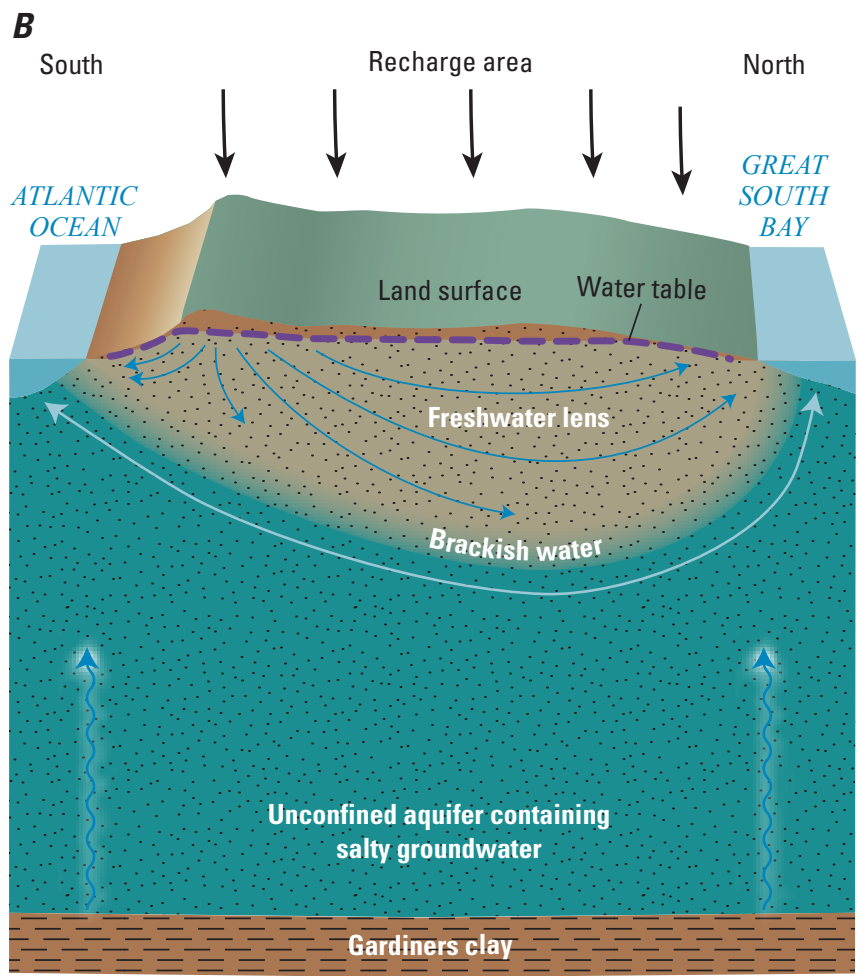

Schematic diagram, not to scale
Figure 4. Block diagrams show that Fire Island is underlain by an aquifer system that consists of $(A)$ unconsolidated deposits of clay, silt, sand, and gravel along the southern shore of Long Island, and $(B)$ the directions of fresh and brackish groundwater flows beneath Fire Island, N.Y. are toward the Atlantic Ocean and Great South Bay (General location of section $A-A^{\prime}$ is shown in figure 1.) 


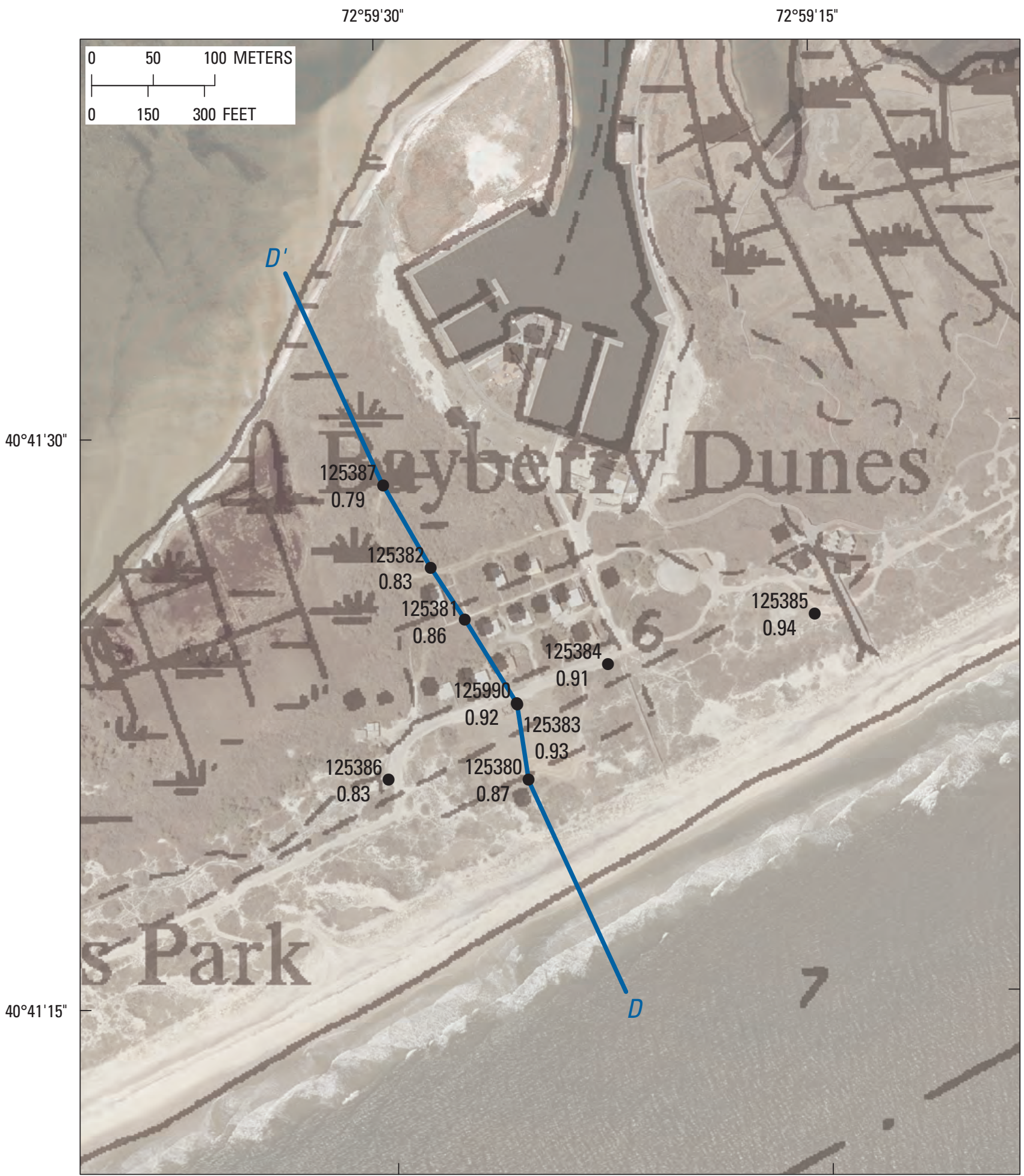

Base from New York State Department of Transportation planimetric quadrangles, 1991, 1:24,000; Universal Transverse Mercator projection, NAD 83, Zone 18

\section{EXPLANATION}

$D-D^{\prime}$ Trace of Hydrogeologic Section--Shows location of vertical section shown in figure 6.

125387 Observation Well--Upper number is identifier. Prefix "S" denoting Suffolk County is omitted. Lower number is water level, in meters above NGVD 29.

Figure 5. Map shows the location of cross section D-D' drawn across Watch Hill, and observation wells drilled to document the geology, measure groundwater levels, and collect water-quality data in Suffolk County, N.Y. 


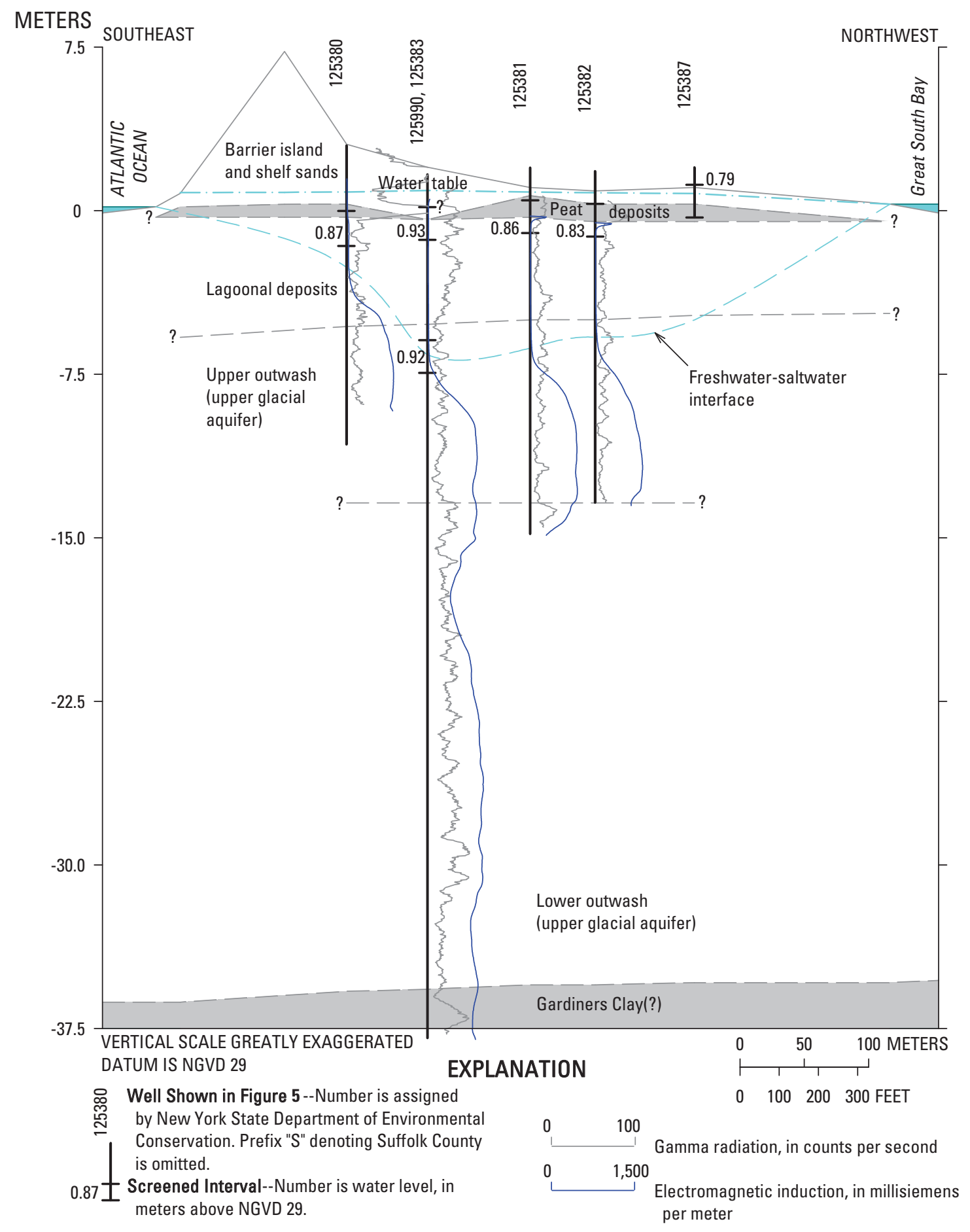

Figure 6. Cross section of the Watch Hill study area (figure 5) shows the arrangement of layers of surficial, glacial, and nonglacial deposits beneath the land surface, where freshwater meets saltwater, the water table, and groundwater levels measured in observation wells from October 31 to November 1, 2005 on Fire Island, Suffolk County, N.Y. 


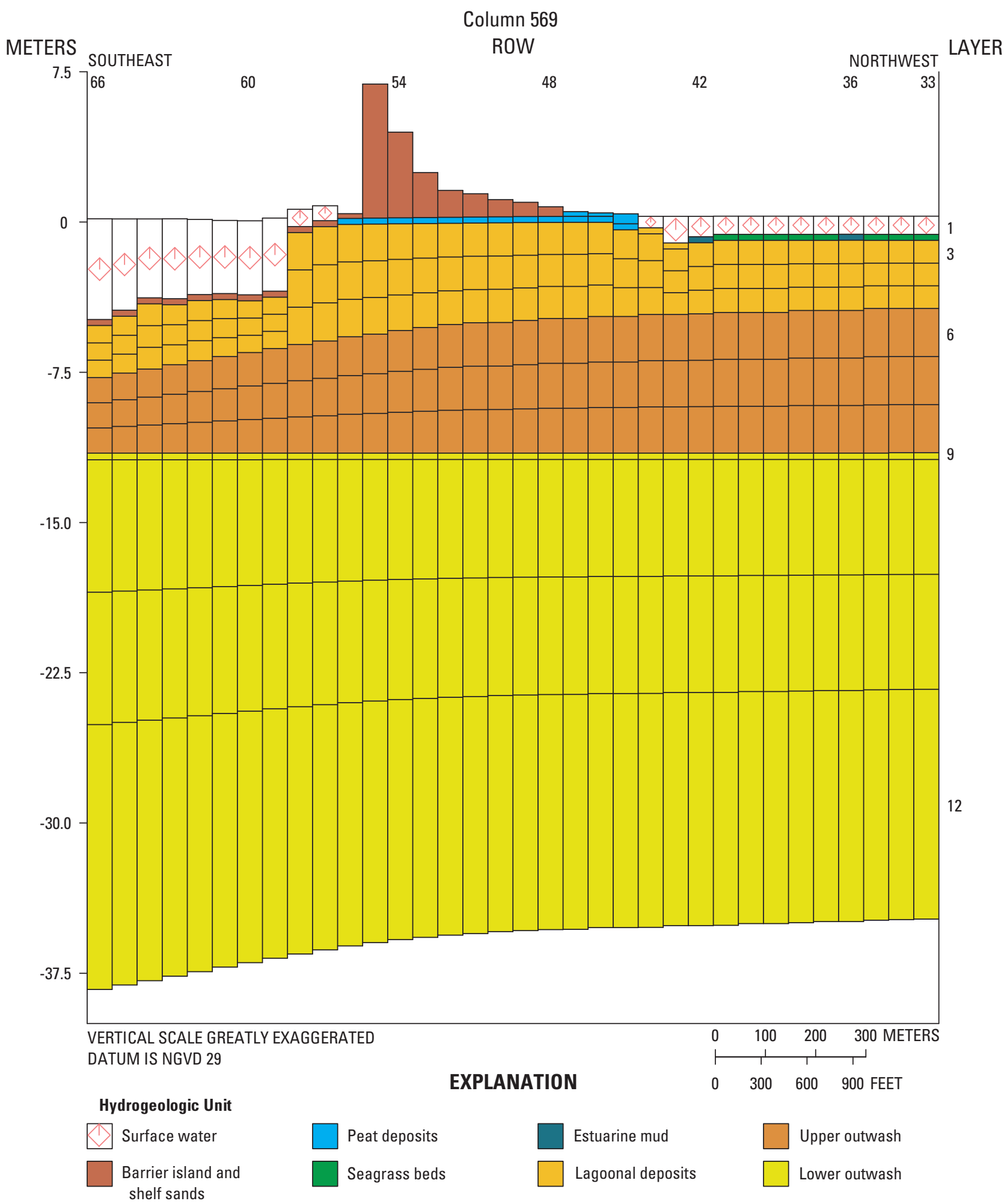

Figure 7. Cross section shows an example of how the shallow-aquifer system beneath the Fire Island study area can be recreated in a groundwater-flow model grid. Models can be used to represent geologic sediment layers and estimate rates and directions of groundwater flow through those layers to simulate groundwater flow. 


\section{Model Grid}

The movement of fresh groundwater on Fire Island is controlled by the distribution of hydraulic head, which in turn is controlled by the boundary conditions and hydraulic properties of the freshwater flow system. The model was designed to simulate the steady-state groundwater flow directions, velocities, and discharge rates in the shallow flow system under 2005 mean annual hydrologic conditions.

The model grid encompasses the full breadth of Fire Island (as mapped by Klopfer and others, 2002) and consists of 72 rows, 1,008 columns, and 12 vertical layers. The grid has a uniform horizontal discretization of $50 \mathrm{~m}(164 \mathrm{ft})$ along rows and columns and is oriented 20.16 degrees counterclockwise from true north. The model represents the full thickness of the shallow aquifer system from the water table to the base of the upper glacial aquifer (fig. 4); layer thicknesses vary from cell to cell and generally were based on the geometry of the hydrogeologic units. The grid contains a total of 870,912 cells, of which 367,752 are active, and 503,160 are inactive.

The model represents each of the Late Pleistocene and Holocene units. Layer 1 represents three surficial Holocene units (upper outwash, peat deposits, and barrier and shelf sands) in onshore areas and also represents surface-water bodies (figs. 6 and 7). Layer 2 represents an underlying lens of peat deposits in onshore areas and five surficial Holocene units (lagoonal deposits, estuarine mud, seagrass beds, peat deposits, and barrier and shelf sands) in back-bay and ocean areas. Layers 3,4 , and 5 represent lagoonal deposits except along the Long Island mainland, where these layers represent the upper outwash of the upper glacial aquifer. Layers 6, 7, and 8 represent upper outwash. Layer 9 represents the " 20 -foot" clay, except in areas where this unit is absent; in these areas, layer 9 represents the lower outwash of the upper glacial aquifer. Layers 10 and 11 represent the lower outwash. Layer 12 represents the finegrained, basal part of this unit.

\section{Model Boundary Conditions}

The boundary conditions specified in the flow model coincide with the hydraulic boundaries of the freshwater flow system under 2005 conditions. These boundaries were assumed to be constant through time and were used to simulate groundwater flow under steady-state, average annual conditions.

A no-flow condition was specified at the lateral boundary between active and inactive model zones in all layers. This boundary condition was also applied at the bottom of the lowermost model layer (layer 12; fig. 7), which represents the base of the upper glacial aquifer. Poorly permeable units beneath this aquifer - the Gardiners Clay and Monmouth greensand (fig. 4) - hydraulically isolate the upper glacial aquifer from the underlying Magothy aquifer (Scorca and others, 1995).

Constant-head boundaries were applied in estuaries and the ocean to represent the flow of water from the shallow aquifer to marine surface waters (layer 1). Local measured or calculated differences in surface-water levels were extrapolated throughout the back bays and ocean to depict local mean sea level (MSL) to which the total water-table overheight, resulting from wave setup and setdown and tidal pumping, was added.
Constant-concentration boundaries: Long-term salinitymeasurement records (R.M. Waters, Suffolk County Department of Health Services, written commun., 2006; National

Oceanographic Data Center, 2006) were extrapolated to provide a time-averaged depiction of salinity throughout the backbarrier estuaries and the ocean.

A specified-flux boundary was applied at the water table (layer 1) to represent recharge from precipitation and the return flow of public-supply water. Inland surface-water bodies (layer 1) were simulated as areas of high hydraulic conductivity $(15,000 \mathrm{~m} / \mathrm{d}$ or $50,000 \mathrm{ft} / \mathrm{d})$ and porosity (1). These boundaries were simulated as described below.

- Recharge from precipitation was simulated by five zones that represented increasing rates of infiltration to the water table. The zone boundaries were delineated, and the values were assigned according to type of substrate, type of land cover, and land-surface elevation. Public-supply withdrawal was not simulated because virtually all water-supply pumpage is from the deeper (unmodeled) Magothy aquifer.

- Recharge from the return flow of public-supply water was simulated by a series of rates that were assigned according to the water-supply system and the return-flow component (distribution or waste). The rates of public-supply return flow within the unsewered areas were calculated as 85 percent of the total 2005 pumpage for these areas, divided by the number of square kilometers (square miles) in each service area. The rate of public-supply return flow in the sewered community of Ocean Beach was calculated as 15 percent of the total 2005 pumpage for this system, divided by the number of square kilometers in its service area. Rates of public-supply return flow for the distribution systems and wastewater systems associated with Smith Point County Park and the NPS visitor centers at Sailors Haven, Watch Hill, and the National Wilderness generally were calculated as 15 percent for the distribution systems and 70 percent for the wastewater systems.

\section{Model Calibration}

The flow model was calibrated through a quasi steady-state simulation of 2005 mean annual conditions. Simulated water levels were then compared with water-level measurements made at the 35 observation wells on October 31 and November 1, 2005.

Simulated salinities (salt concentrations) were compared qualitatively with the positions of the freshwater-saltwater interface as estimated from salinity values measured at 21 wells during the study.

Horizontal and vertical hydraulic-conductivity values for the simulated hydrogeologic units were adjusted through trial and error until the differences between measured and simulated groundwater levels were minimized. The model was considered calibrated when the difference between measured and simulated values at wells representing the principal hydrogeologic units in each of the four study areas (fig. 2) were at their smallest.

\section{Groundwater Levels and Divide}

Simulated hydraulic heads in the unconfined flow system (and underlying confined flow systems) generally increase 


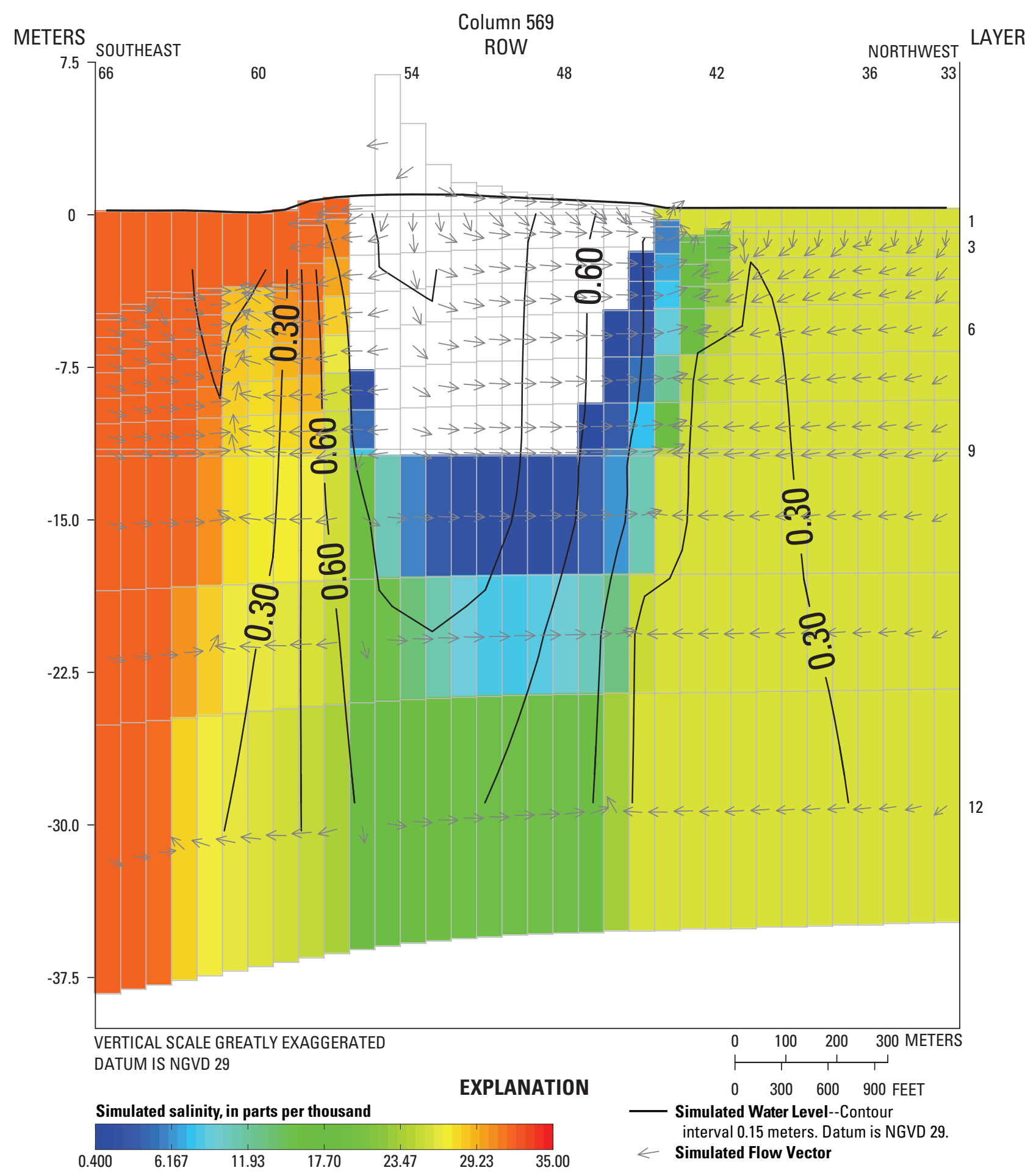

Figure 8. Model grid shows simulated 2005 mean annual water levels, the location of the groundwater divide beneath the barrier island near the ocean shore toward the southeast (indicated by opposing flow arrows near row 54), and the direction of ground-water flow beneath most of the Fire Island study area toward the northwest and the back-barrier estuaries.

with proximity to the ocean shore, where the modeled effects of wave setup and tidal pumping result in a water-table overheight. The simulated groundwater divide throughout Fire Island is strongly skewed toward the ocean shore in response to this water-table overheight; it also extends nearly to the base of the shallow aquifer system where the island is wide and thus probably restricts the exchange of subsurface flow between back-barrier estuaries and the ocean. Where the island is relatively narrow, however, the heads are lower, and the divide originates along the ocean shore. This presumably enhances downward movement of saline water such that it may subsequently migrate northward beneath the freshwater flow system to back-barrier estuaries. An example of simulated water levels, flow vectors, and extent of freshwater within the shallow aquifer system along column 569 (near location of section D-D' shown in fig. 5) is presented in figure 8. 


\section{Discharge-Boundary Flows}

Groundwater discharges to marine surface waters were estimated through analyses of discharge-boundary flows and areas that contribute recharge. Results of the dischargeboundary analyses were consistent with earlier conceptual and numerical model results of barrier-island groundwater flow. Uncertainties in the discharge-boundary estimates indicate, however, that the discharge values for the respective rechargecontributing areas probably should be considered qualitative (rather than quantitative) approximations of freshwater flow.

\section{Contributing-Area Analysis}

All freshwater discharge from the shallow aquifer system to back-barrier estuaries and the ocean originates at the water table in recharge areas. The areas that are sources of recharge entering these water bodies were delineated through the forward tracking of an individual particle placed at the center of each model cell that received recharge. The particle-tracking postprocessing package MODPATH (Pollock, 1994) was used in the analysis. Simulated contributing areas to marine surface waters under 2005 mean annual conditions are shown in figure 9. The simulated divide between areas that contribute recharge to back-barrier estuaries and those that contribute recharge to the ocean is skewed strongly toward the ocean shore, where the modeled effects of wave setup and tidal pumping result in the water-table overheight. Recharge from areas that do not discharge to these water bodies was assumed to exit the system as subsea underflow.

\section{Groundwater Budgets}

Groundwater budgets were developed for recharge areas that contribute freshwater to back-barrier estuaries, the ocean, and subsea-discharge zones. These budgets were developed from results of the contributing-area analysis and indicate that the total freshwater discharge to back-barrier estuaries is about $43,500 \mathrm{~m}^{3} / \mathrm{d}\left(1,540,000 \mathrm{ft}^{3} / \mathrm{d}\right)$ or 79.8 percent of total freshwater discharge from the shallow-aquifer system. In contrast, discharge to the ocean is only about 25 percent of that amount $-10,200 \mathrm{~m}^{3} / \mathrm{d}\left(360,000 \mathrm{ft}^{3} / \mathrm{d}\right)$ or 18.7 percent of total freshwater discharge from the shallow aquifer system. Another 1.5 percent $\left(836 \mathrm{~m}^{3} / \mathrm{d}\right.$ or $\left.29,500 \mathrm{ft}^{3} / \mathrm{d}\right)$ may exit the system as subsea underflow.

The contributing-area analysis also provided estimates of the travel times for individual particles from their point of entry at the water table to their point of discharge at the shore. Results of the particle tracking indicate the median age of groundwater (travel time from the point of recharge to the point of discharge at back-barrier estuaries and the ocean) was 3.4 years, depending on the distance between recharge point and the shore. Virtually all groundwater (95th percentile) was found to be younger than 20 years.

\section{Total Nitrogen Concentrations and Loads}

Freshwater entering the water table as precipitation that has infiltrated through the soil, and wastewater that enters the water table from on-site septic systems in unsewered areas, contain nitrogen in concentrations that vary with the location and the rate at which it is introduced, and also with the flow paths and travel time of water in which it moves. Nitrogen concentrations can be altered through physical processes such as dilution and dispersion; the form of nitrogen entering groundwater also can be altered through biogeochemical processes such as denitrification, whereby it is ultimately converted to nitrogen gas. The form of nitrogen that predominates in a given system, whether as nitrate, ammonia, or organic nitrogen, is controlled by the $\mathrm{pH}$ and redox conditions in the water (Hem, 1985).

Nitrate is an oxidized form of nitrogen that can be transported conservatively in groundwater. Ammonia is a reduced form of nitrate that strongly sorbs to aquifer sediments (Hem, 1985). Total nitrogen (TN) was computed in this study as the sum of the concentrations of ammonia and nitrite plus nitrate.

The TN loads entering back-barrier estuaries and the ocean as shallow groundwater discharge were calculated as the model-generated groundwater discharges multiplied by the representative TN concentrations for the principal land uses on Fire Island. The TN concentrations in undeveloped and developed park areas were assumed to be 0.29 and $1.63 \mathrm{mg} / \mathrm{L}$ as $\mathrm{N}$, respectively. These values were the median TN concentrations in water samples collected from 16 shallow wells in October 2005 ( 7 in undeveloped park areas and 9 in developed park areas).

$\mathrm{TN}$ concentrations for the residential communities within FIIS were assumed to be comparable to published values for similar communities on the south shore of Suffolk County (Monti and Scorca, 2003). The nitrogen concentration for communities with mostly low- to medium-density residential development was estimated in this study to be generally equivalent to a median TN concentration of $1.19 \mathrm{mg} / \mathrm{L}$, and that for communities consisting primarily of high-density residential development was $2.69 \mathrm{mg} / \mathrm{L}$. The nitrogen concentration for the sewered community of Ocean Beach was estimated to be generally equivalent to a median TN value of $0.86 \mathrm{mg} / \mathrm{L}$. The TN concentrations measured at four wells downgradient from the communities of Kismet and Robbins Rest showed reasonable agreement with the median TN concentrations calculated by Monti and Scorca (2003). Therefore, the values from that study probably can be considered reasonable approximations of the median $\mathrm{TN}$ concentrations for Fire Island communities, as summarized in the table:

\begin{tabular}{cc}
\hline $\begin{array}{c}\text { Median TN concentration } \\
\text { estimated for south shore of } \\
\begin{array}{c}\text { Suffolk County mainland } \\
\text { (Monti and Scorca, 2003) }\end{array}\end{array}$ & $\begin{array}{c}\text { Corresponding } \\
\text { Fire Island } \\
\text { community }\end{array}$ \\
\hline $\begin{array}{c}1.19 \mathrm{mg} / \mathrm{L} \text { for unsewered area } \\
\text { east of Carmans River }\end{array}$ & $\begin{array}{c}\text { Unsewered low and medium } \\
\text { density residential } \\
\text { development }\end{array}$ \\
$\begin{array}{c}\text { d.69 mg/L for unsewered area } \\
\text { west of Carmans River }\end{array}$ & $\begin{array}{c}\text { Unsewered high density } \\
\text { residential development }\end{array}$ \\
$0.86 \mathrm{mg} / \mathrm{L}$ for Southwest Sewer & $\begin{array}{c}\text { Sewered community of } \\
\text { Ocean Beach }\end{array}$ \\
\hline
\end{tabular}

Communities in the mainland areas, where residency is mostly year-round, probably generate a larger annual wastewater TN load than areas occupied mainly during summer. Nevertheless, the wastewater TN load produced by the intense summer visitation of Fire Island could exceed the summer load produced by a permanent population on the mainland. 

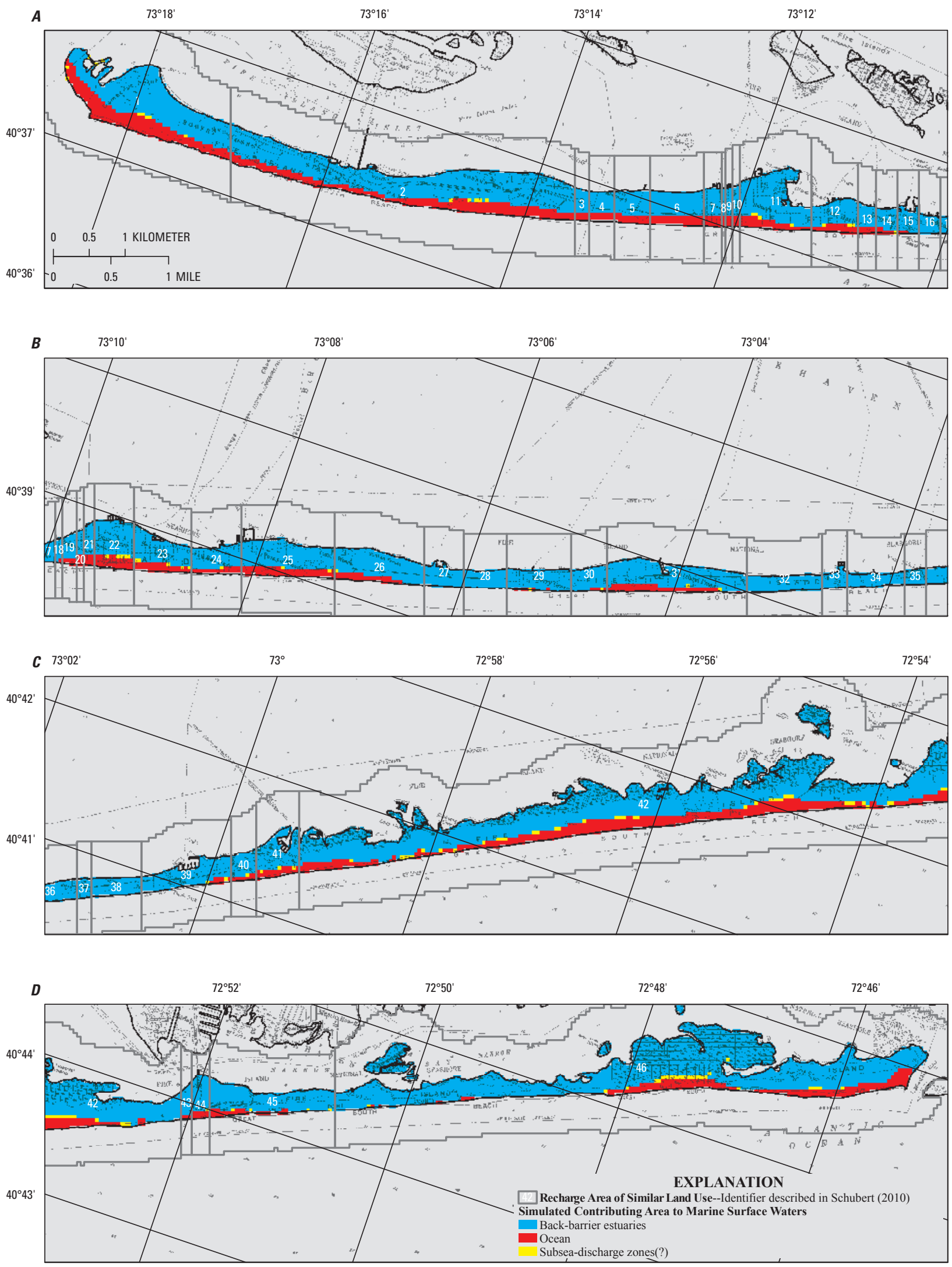

Base from New York State Department of Transportation planimetric quadrangles, 1991, 1:24,000 Universal Transverse Mercator projection, NAD 83, Zone 18

Figure 9. Maps of simulated recharge areas (numbered in white) to marine surface waters under 2005 mean annual conditions show that most freshwater from the shallow aquifer system discharges toward the back-barrier estuaries (recharge areas in blue) in the Fire Island study area, Suffolk County, N.Y. (Locations of areas are shown in panels $A, B, C$, and $D$ in figure 2.) 
A Distribution and amount of annual total nitrogen load from Fire Island

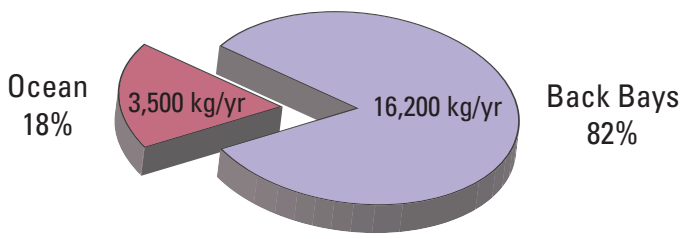

\section{$B$ Sources of total nitrogen load to back bays by land use on Fire Island}

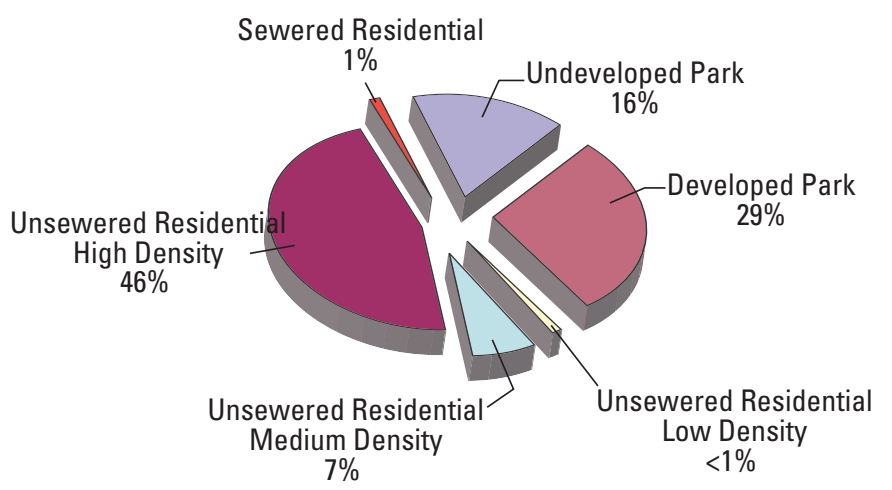

Figure 10. Pie charts show total nitrogen load in groundwater discharge $(A)$ distribution by percent and kilograms per year $(\mathrm{kg} / \mathrm{yr})$ to back bays and the ocean, and $(B)$ sources of TN load to back bays by percent of contributing land-use area from Fire Island, Suffolk County, N.Y.

The TN concentrations and loads calculated for 2005 mean annual conditions in areas that contribute fresh groundwater to back-barrier estuaries and the ocean were calculated for developed and undeveloped areas on Fire Island. Results indicate that, of the total annual TN load discharged from the shallow aquifer system, 82.2 percent (about 16,200 kg/yr or $35,700 \mathrm{lb} / \mathrm{yr}$ ) is distributed to shoreline discharge zones along the back bays (fig. 10A), and the remaining 17.8 percent (about $3,500 \mathrm{~kg} / \mathrm{yr}$ or $7,720 \mathrm{lb} / \mathrm{yr}$ ) is to the ocean. TN loads entering back bays from the shallow aquifer system are presented below according to contributing land-use area (fig. 10B):

- Undeveloped park areas: 16.0 percent of total annual load $(2,590 \mathrm{~kg} / \mathrm{yr}$ or $5,710 \mathrm{lb} / \mathrm{yr})$;

- Developed park areas: 29.2 percent of total annual load $(4,730 \mathrm{~kg} / \mathrm{yr}$ or $10,400 \mathrm{lb} / \mathrm{yr})$;

- Unsewered residential areas:

low density: 0.4 percent of the total annual load (63 kg/yr or $140 \mathrm{lb} / \mathrm{yr})$; medium density: 7.3 percent of the total annual load $(1,190 \mathrm{~kg} / \mathrm{yr}$ or $2,620 \mathrm{lb} / \mathrm{yr})$;

high density: 45.7 percent of the total annual load $(7,400 \mathrm{~kg} / \mathrm{yr}$ or $16,300 \mathrm{lb} / \mathrm{yr})$;

- Sewered residential area: 1.3 percent of the total annual load (203 kg/yr or $448 \mathrm{lb} / \mathrm{yr}$ ).
The total TN load from Fire Island to marine surface waters is calculated to be $19,700 \mathrm{~kg} / \mathrm{yr}(43,420 \mathrm{lb} / \mathrm{yr})$, equivalent to roughly 6 percent of the annual TN load of about $345,000 \mathrm{~kg} / \mathrm{yr}(761,000 \mathrm{lb} / \mathrm{yr})$ that is discharged from shallow groundwater from the Suffolk County mainland into the South Shore Estuary Reserve (SSER) (Monti and Scorca, 2003). In contrast to the total annual TN load from the entire $1,420-\mathrm{km}^{2}$ SSER study area, which yields about $353 \mathrm{~kg}$ of nitrogen per square kilometer $\left(300 \mathrm{lb} / \mathrm{mi}^{2}\right)$ annually, the total annual TN loading rate from Fire Island is about $890 \mathrm{~kg} / \mathrm{km}^{2}$ $\left(758 \mathrm{lb} / \mathrm{mi}^{2}\right)$ - nearly three times the annual loading rate from the SSER (fig. 11) and nearly twice the reported annual loading rate from shallow groundwater along the north shore of Nassau and Suffolk Counties $\left(458 \mathrm{~kg} / \mathrm{km}^{2}\right.$ or $\left.390 \mathrm{lb} / \mathrm{mi}^{2}\right)$ to Long Island Sound (Scorca and Monti, 2001).

\section{Limitations of Analysis}

Simulations of groundwater discharge and calculations of nitrogen loads have several inherent limitations that are summarized briefly below:

1. The total estimate of water-table overheight resulting from wave setup and tidal pumping along the Atlantic Ocean shore of Fire Island relies on simplified terms and probably can be considered a conservative approximation. It also is based on a static shoreline position that, in reality, is dynamic, partly as a result of changes in wave climate that also may affect the amount of overheight.

2. Coarse model discretization requires averaging over large spatial and temporal scales and, therefore, limits the precision of simulated groundwater-flow patterns and rates and the resulting nitrogen-loading calculations. Because the calibration was limited to groundwater levels, the model is nonunique; that is, variations in hydraulic conductivity and recharge are most likely inversely correlated (an increase in one produces the same change in hydraulic head as a decrease in the other). Although no formal sensitivity analysis was done, addition of the water-table overheight condition during model development strongly affected simulated water levels, particularly along the ocean shore.

3. Variations in the no-flow condition specified for the base of the upper glacial aquifer could allow flow through the underlying, poorly permeable units and, thereby, affect model results but probably to a lesser extent than (2).

4. Simulations of variable-density groundwater flow were run to delineate the steady-state extent of the freshwater lens under 2005 conditions. The modeled hydrologic boundaries were assumed to be constant through time even though they can undergo large fluctuations from storm tides and other short-term factors such as storm overwash and coastal flooding. As a result, the model probably overestimated the depth of the freshwater lens, particularly in deeper, confined zones where travel times for freshwater recharge are extended. Consequently, transientstate modeling of historical conditions could provide information on the extent to which short-term fluctuations in hydrologic boundaries affect groundwater discharge and nitrogen loads. 
5. The use of TN concentrations to calculate nitrogen loads may overestimate mass-loading rates through the assumption of conservative transport in groundwater. Additional uncertainties in the estimated nitrogen loads from residential areas on Fire Island include (1) estimation of TN concentrations from values calculated for the south shore Suffolk County mainland and (2) reliance on median $\mathrm{TN}$ concentrations at four wells downgradient from two communities to assess the suitability of these surrogate values in calculating nitrogen loads.

\section{Groundwater-Resource Concerns}

The future of Fire Island and its surrounding water bodies will depend partly on whether human-derived contamination can be controlled. The major concerns, listed below, represent the primary groundwater-resource concerns identified in this study.

1. High-density residential land occupies only about 8 percent of Fire Island, yet its unsewered areas contribute almost half of the total TN load from the shallow aquifer system to back-barrier estuaries.

2. Water-table overheight directs about 80 percent of freshwater recharge on Fire Island to back-barrier estuaries through the combined effects of wave setup and tidal pumping along the ocean shore. As a result, the development of groundwater-protection strategies may warrant consideration of most of the island as a potential source area of nutrients entering the wetland and adjacent estuarine habitats within the boundaries of FIIS.

3. The water sampling that was done in this study typically showed extremely low TN concentrations in undeveloped park areas, yet TN concentrations were elevated locally in park areas downgradient from at least two communities, Kismet and Robbins Rest, and downgradient from the Watch Hill leach field. Although the elevated concentrations were within the range of those commonly found in developed areas of the Long Island mainland, they exceeded the background levels observed in undeveloped park areas at FIIS by a factor of 10 or more. This considerable increase in TN concentrations associated with human activities could affect terrestrial and aquatic (freshwater and brackish) habitats and species that are adapted to the low nutrient concentrations generally found within and downgradient from undeveloped areas.

4. Elevated nutrient concentrations in groundwater underlying undeveloped areas indicate that recharge containing sewage, fertilizers, and (or) other human-derived products has infiltrated the water table in upgradient areas. This contaminated recharge could also contain pathogens and other manmade substances such as organic compounds that can move through the shallow aquifer and enter the surrounding water bodies, where they could threaten the ecological health of aquatic and coastal habitats.

\section{Considerations for Future Monitoring}

Groundwater discharge sustains freshwater ponds and wetlands; it also helps control salinity and maintain the biological diversity and productivity of estuaries and salt

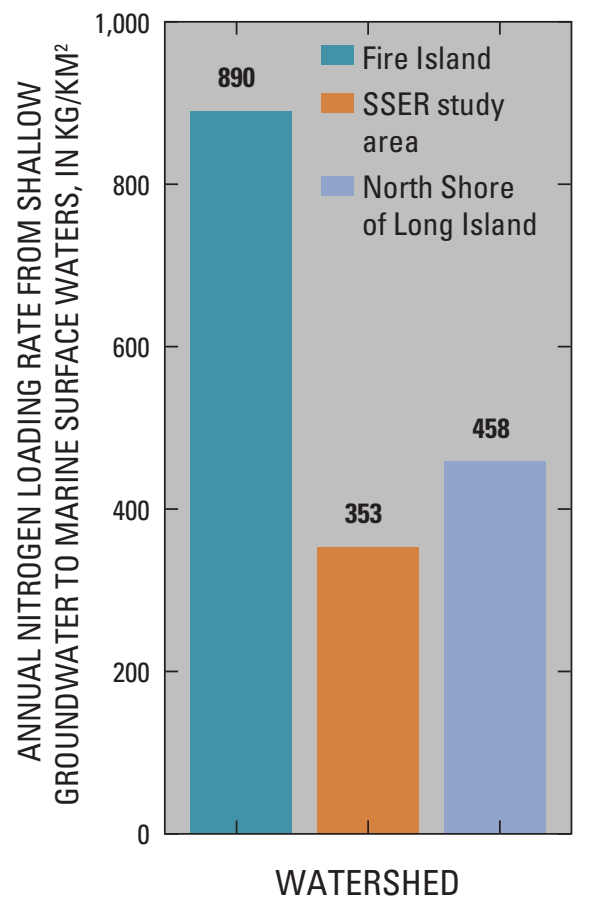

Figure 11. Graph shows the rate of annual discharge of nitrogen from shallow groundwater to marine surface waters in the Fire Island, South Shore Estuary Reserve (SSER), and North Shore of Long Island watersheds on Long Island, N.Y. The rate of nitrogen discharge is estimated in kilograms per square kilometer $\left(\mathrm{kg} / \mathrm{km}^{2}\right)$.

marshes (Masterson and Portnoy, 2005). Therefore, long-term water-level and water-quality monitoring is critical for the development of strategies to protect the groundwater system and the freshwater and estuarine ecosystems that depend on it.

Continuous, monthly, and annual groundwater monitoring would provide a seasonal and long-term database for detection of current and future trends in water levels and in concentrations of selected constituents. This could be achieved through a network of 12 wells that bisect Fire Island in the four local areas detailed in this study. Future trends in nutrient concentrations in recharge entering the groundwater system and in discharge to the back bays and ocean could be monitored through annual collection of water samples from at least two of these wells in each of the four local study areas. The annual sampling for nutrient concentrations at these wells could include samples for organic-compound and (or) pathogen analysis. Development of a record of detections of a variety of constituents would enhance the database.

Nutrient concentrations measured during this study were low in undeveloped park areas but elevated locally in areas downgradient from communities and the NPS facility at Watch Hill. Therefore, any monitoring program designed to detect upward trends in these concentrations would include sampling in developed and undeveloped areas and analyses to identify contamination from sewage, fertilizers, and (or) other human-derived substances, including pathogens and organic compounds. An alternative approach could be the collection of water samples within the communities themselves. Thus, a plan for the future installation of additional monitoring wells in the target areas would be needed. 


\section{References Cited}

Bokuniewicz, H.J., McElroy, A., Schlenk, C., and Tanski, J., eds., 1993, Estuarine resources of the Fire Island National Seashore and vicinity: New York Sea Grant Institute Report NYSGI-T-93-001, 79 p. (plus appendixes).

Franke, O.L., and McClymonds, N.E., 1972, Summary of the hydrologic situation on Long Island, N.Y., as a guide to water-management alternatives: U.S. Geological Survey Professional Paper 627-F, 59 p.

Hanslow, D., and Nielsen, P., 1993, Shoreline setup on natural beaches, in Short, A.D., ed., Beach and surfzone morphodynamics: Journal of Coastal Research, Special Issue 15, p. 1-11.

Hem, J.D., 1985, Study and interpretation of the chemical characteristics of natural water ( $3 \mathrm{~d}$ ed.): U.S. Geological Survey Water-Supply Paper 2254, 225 p.

Klopfer, S.D., Olivero, Adele, Sneddon, Lesley, and Lundgren, Julie, 2002, Final report of the NPS Vegetation Mapping Project at Fire Island National Seashore: Blacksburg, Va., College of Natural Resources at Virginia Tech, Conservation Management Institute Report CMI-GRS-02-03, 205 p.

Langevin, C.D., Shoemaker, W.B., and Guo, W., 2003, MODFLOW-2000, the U.S. Geological Survey Modular Ground-Water Model-Documentation of the SEAWAT-2000 Version with the Variable-Density Flow Process (VDF) and the Integrated MT3DMS Transport Process (IMT): U.S. Geological Survey Open-File Report 03-426, 43 p.

Leggette, Brashears \& Graham, Inc., 1996, Ground-water resources of Fire Island, New York: Trumbull, Conn., Leggette, Brashears \& Graham, Inc., variously paged.

Masterson, J.P., and Portnoy, J.W., 2005, Potential changes in ground-water flow and their effects on the ecology and water resources of the Cape Cod National Seashore, Massachusetts: General Information Product 13, 16 p. (Also available at http://pubs.usgs.gov/gip/2005/13/)

Monti, Jack, Jr., and Scorca, M.P., 2003, Trends in nitrogen concentration and nitrogen loads entering the South Shore Estuary Reserve from streams and ground-water discharge in Nassau and Suffolk Counties, Long Island, New York, 1952-97: U.S. Geological Survey Water-Resources Investigations Report 02-4255, 36 p.

National Oceanographic Data Center, 2006, NODC Interactive Data Access and Retrieval System: accessed May 18, 2006, at http://www.nodc.noaa.gov/dsdt/index.html

National Park Service, 2002, Mosquito Action Plan (MAP), Fire Island National Seashore-2002: accessed April 24, 2007, at http://www.nps.gov/archive/fiis/MAPfy02.htm
National Park Service, 2003, Finding of No Significant Impact (FONSI), National Park Service (NPS) special use permit issuance for Fire Island community beach scraping and nourishment projects: accessed April 24, 2007, at http://www.nps.gov/fiis/parkmgmt/upload/FONSI CommunityBeachProtectionEA_8-1-03.pdf

National Park Service, 2007, Fire Island National SeashorePark statistics (U.S. National Park Service): accessed April 24, 2007, at http://www.nps.gov/fiis/parkmgmt/statistics.htm

Nielsen, P., 1990, Tidal dynamics of the water table in beaches: Water Resources Research, v. 26, no. 9, p. 2127-2134.

Nielson, P., 1999, Groundwater dynamics and salinity in coastal barriers: Journal of Coastal Research, v. 15, no. 3, p. 732-740.

Pollock, D.W., 1994, User's Guide for MODPATH/MODPATHPLOT, Version 3: A particle tracking post-processing package for MODFLOW, the U.S. Geological Survey finitedifference ground-water flow model: U.S. Geological Survey Open-File Report 94-464, 6 ch.

Schubert, C.E., 2010, Analysis of the shallow groundwater flow system at Fire Island National Seashore, Suffolk County, New York: U.S. Geological Survey Scientific Investigations Report 2009-5259, 106 p. (Also available at http://pubs.usgs.gov/sir/2009/5259/)

Scorca, M.P., and Monti, Jack, Jr., 2001, Estimates of nitrogen loads entering Long Island Sound from ground water and streams on Long Island, New York, 1985-96: U.S. Geological Survey Water-Resources Investigations Report 00-4196, 29 p.

Scorca, M.P., Reilly, T.E., and Franke, O.L., 1995, Selected hydrogeologic and water-quality data from Jones Beach Island, Long Island, New York: U.S. Geological Survey Water-Resources Investigations Report 92-4171, 21 p.

Turner, I.L., Coates, B.P., and Acworth, R.I., 1996, The effects of tides and waves on water-table elevations in coastal zones: Hydrogeology Journal, v. 4, no. 2, p. 51-69.

Valiela, Ivan, Foreman, Kenneth, LaMontagne, Michael, Hersh, Douglas, Costa, Joseph, Peckol, Paulette, DeMeo-Andreson, Barbara, D’Avanzo, Charlene, Babione, Michele, Sham, Chi-Ho, Brawley, John, and Lajtha, Kate, 1992, Couplings of watersheds and coastal waters: sources and consequences of nutrient enrichment in Waquoit Bay, Massachusetts: Estuaries and Coasts, v. 15, no. 4, p. 443-457.

By Christopher E. Schubert, M. Peter deVries, and Anne J. Finch

\author{
For more information, please contact: \\ U.S. Geological Survey \\ New York Water Science Center \\ 2045 Route 112, BIdg. 4 \\ Coram, NY 11727 \\ (631) 736-0783 \\ http://ny.water.usgs.gov
}

